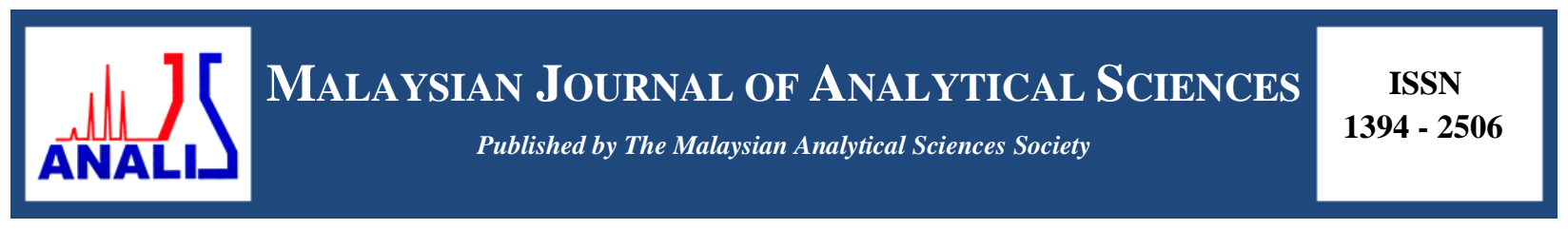

\title{
STRUCTURAL STUDY OF REDUCED GRAPHENE OXIDE/POLYPYRROLE COMPOSITE AS METHANOL SENSOR IN DIRECT METHANOL FUEL CELL
}

\author{
(Kajian Struktur Komposit Grafin Oksida Terturun/Polipirol Sebagai Sensor Metanol Dalam Sel \\ Bahan Api Metanol Langsung) \\ Mumtazah Atiqah Hassan ${ }^{1}$, Siti Kartom Kamarudin ${ }^{1,2}$, Kee Shyuan Loh $^{1}$ \\ ${ }^{1}$ Fuel Cell Institute \\ ${ }^{2}$ Department of Chemical and Process Engineering, Faculty of Engineering and Built Environment \\ Universiti Kebangsaan Malaysia, 43600 UKM Bangi, Selangor, Malaysia \\ *Corresponding author: ctie@ukm.edu.my
}

Received: 5 February 2016; Accepted: 22 April 2016

\begin{abstract}
Density functional theory (DFT) computations were performed on the optimized geometric and electronic properties of reduced graphene oxide/polypyrrole (rGO/PPy) composite in comparison with pure graphene and graphene oxide structures. Incorporation of both reduced GO (rGO) and PPy will form a good composite which have advantages from both materials such as good mechanical strength and excellent electrical conductivity. These composite would be very suitable in fabrication of methanol sensor in direct methanol fuel cell (DMFC). The HOMO-LUMO energy $(\mathrm{eV})$ was also calculated. These computational calculations provide a theoretical explanation for the good performance of $\mathrm{rGO} / \mathrm{PPy}$ composite as electrode materials in methanol sensor.
\end{abstract}

Keywords: graphene, structure, polypyrrole, direct methanol fuel cell, density functional theory

Abstrak

Pengiraan teori fungsi ketumpatan (DFT) telah dilakukan ke atas ciri-ciri optimum geometri dan elektronik oksida komposit grafin terturun/polipirol (rGO/PPy) berbanding dengan grafin tulen dan grafin oksida. Gabungan kedua-dua GO terturun (rGO) dan PPy akan membentuk komposit yang baik yang mempunyai kelebihan dari kedua-dua bahan seperti kekuatan mekanikal dan kekonduksian elektrik yang sangat baik. Komposit ini menjadi sangat sesuai dalam pembuatan sensor metanol dalam sel bahan api metanol langsung (DMFC). Tenaga HOMO-LUMO (eV) juga telah dikira. Pengiraan ini memberikan penjelasan teori untuk prestasi baik rGO/PPy komposit sebagai bahan elektrod dalam sensor metanol.

Kata kunci: grafin, struktur, polipirol, sel bahan api metanol langsung, teori fungsi ketumpatan

\section{Introduction}

Direct Methanol Fuel Cell (DMFC) is a potential device as a source of mobile power which provides advantages such as high energy density, low pollution, fast starting time, lightweight and more compact compare to rechargeable battery and other types of fuel cells. It is also easy to use. DMFC is capable of converting chemical energy directly between the reaction of methanol and oxidant (air or oxygen) into electrical energy [1, 2]. The overall reaction for methanol oxidation is given as Eq. 1 below [3]:

$$
\mathrm{CH}_{3} \mathrm{OH}+\mathrm{H}_{2} \mathrm{O} \longrightarrow \mathrm{CO}_{2}+6 \mathrm{e}^{-}+6 \mathrm{H}^{+} \text {(anode) }
$$


The reaction for the fuel-cell-based sensor expressed as Eq. 2 below:

$$
5 \mathrm{O}_{2}+6 \mathrm{e}^{-}+6 \mathrm{H}^{+} \longrightarrow 3 \mathrm{H}_{2} \mathrm{O} \text { (cathode) }
$$

A constraint to the fuel cell is the fuel cell performance itself in terms of efficiency and low power density due to the low electro-catalyst activity. In addition, the constrains faced by toxicity in the anode as a result of the absorption of the intermediate products, such as carbon monoxide and high methanol crossover through Nafion membranes [4]. The objective of this paper is to investigate the optimized rGO and graphene structure as well as to determining their energy bands.

Polymer composites have showed significant potentials in development of various application areas like electronic devices, supercapacitor, rechargeable electrode and sensors. The usage of carbon based materials such as graphene, carbon black, single wall carbon nanotubes, carbon nanofibres instead of silicate compound layer or synthetic clay are states to be useful in enhancing the electrical and thermal conductivity [5 -7].

Graphene oxide (GO) is one of the member in carbon based materials. GO is chemically modified form of graphene that contains oxygen functional groups such as epoxides, alcohols, and carboxylic acids which contributes to more reactive GO. Sharing the same atomically thin structural framework as graphene, it provide alternative for graphene which is complicated to produce. It recently emerged as a solution-processable material for large-area electronics because it can be deposited readily and uniformly on a variety of substrates. GO contains saturated sp3 carbon atoms bound to oxygen, which makes it an insulator. Transition to a semiconductor through chemical or thermal removal of oxygen allows it to be reduced incrementally so that the electrical conductivity can be tuned over several orders of magnitude [8].

While, conducting polymers such as polypyrrole (PPy) have high conductivity, are lightweight, low in cost, flexible and environmentally friendly but, as electrode materials, the degradation during cycling might happened where the volume of the polymer changes due to the insertion/deinsertion of counter ions [9]. Incorporation of graphene oxide in a conducting polymer matrix leads to the formation of nanocomposites which own advantages from both components. This advantages would be every useful in fabricating the methanol sensor in DMFC. The rGO/PPy composite electrode shows larger specific capacitance, higher rate performance, and better charge-discharge stability [10]. The rGO/PPy composite also provide large surface area which increases the binding sites [11]. According to Chandra and Kim, the PPy component of the composite is effectively lessen the swelling/shrinkage of polymer chains which solve the problem of the usage of PPy.

In this paper, the density functional theory (DFT) is applied to study on optimizing the structure of rGO/PPy composite and to examine the effect on incorporating the PPy as a composite with rGO. The energy of graphene, $\mathrm{GO}$ and rGO/PPy in applying the composite as methanol sensor electrode are also compared.

\section{Calculation details}

\section{Materials and Methods}

The spin-restricted DFT calculation was performed using DMol3 package. All results were obtained by PBE functional the exchange -correlation function within the generalized gradient approximation (GGA). In terms of numerical basis sets, double numerical plus polarization (DNP) was chosen within DFT semi-core pseudopots due to its reasonable accuracy in energy calculation. A lateral $5 \times 3$ cell was selected as the pure graphene. In the geometrical optimization, all structures were relaxed until the total energy were converged to $1.0 \times 10^{-4}$ Hatree. The maximum force converged to less than $2 \times 10^{-2}$ Hartree/Å, and the maximum displacement convergence was

$5 \times 10^{-2} \AA$. All structures were fully optimized without any symmetry constraint. Figure 1 show the structures of graphene and rGO of Min and Chang et al. [12] and Bagri et al. [13] respectively. 


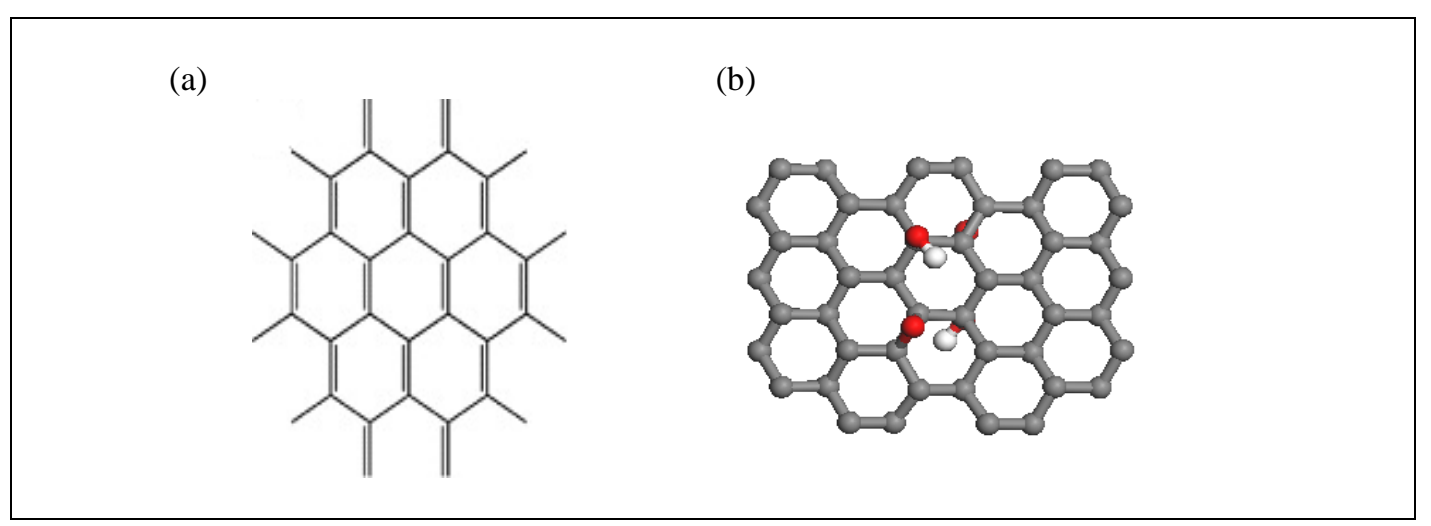

Figure 1. Min and Chang model structure of graphene (a) and Bagri et al. structure of graphene oxide (b)

\section{Results and Discussion}

Figure 2 shows the optimized structure of pure graphene based on structure proposed by Min and Chang. It consists of 42 atoms of carbon. The use of hydrogen atoms in terminating the boundaries of graphite cluster model is a good choice for simulation purposes [14].

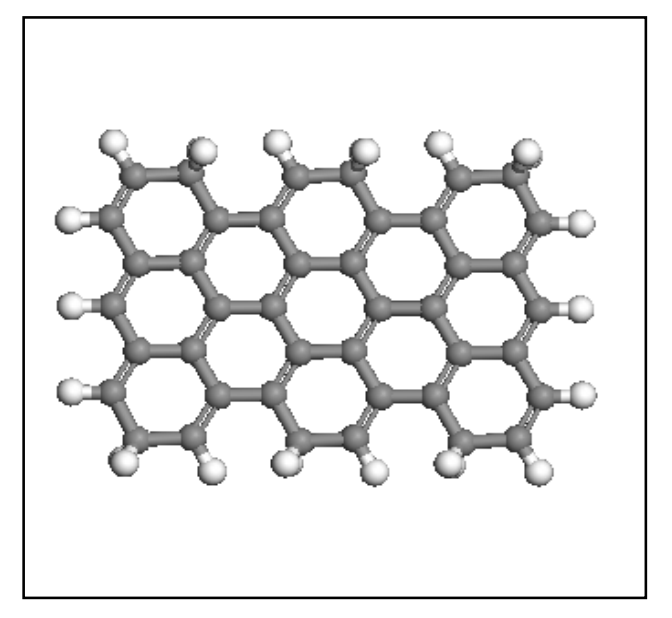

Figure 2. The modelled optimized structure of graphene

For graphene, the calculation is done in two different basis set, DSPP and all-electron basis set to determine which give the lowest value. The calculated value of DSPP, which is $-1597.89 \mathrm{Ha}$ is taken into consideration due to diverging that occur when using all-electron basis set. The optimized rGO is shown in Figure 3. The calculated properties of optimized rGO structure were compared with the graphene structure. The total energy of optimized rGO is $-2051.3074 \mathrm{Ha}$.

From Table 1, the both value were compared. The optimized rGO have lower total energy than graphene. This proves that optimized rGO is more stable than graphene. Liu et al. [15] stated that the edge defects arising from the epoxide and carbonyl groups caused the electrical conductivity of functionalized graphene oxide is several orders of magnitude lower than graphene. The electronic properties of rGO, the highest occupied molecular orbital (HOMO) 
and lowest unoccupied molecular orbital (LUMO) were also calculated. Result shows that, rGO also has lower HOMO-LUMO energy. This showed that graphene has higher binding energy compared to rGO.

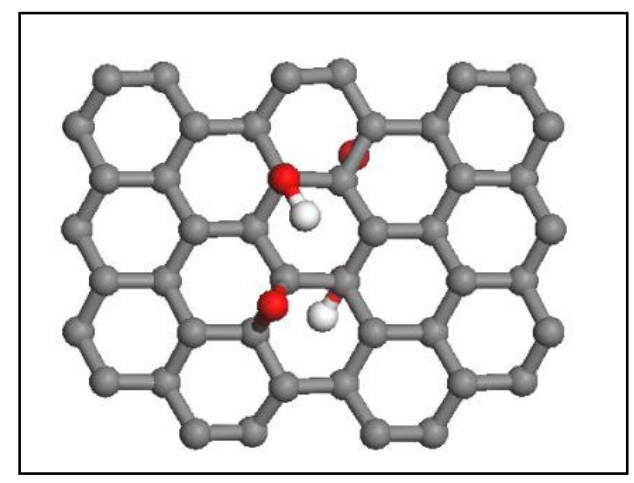

Figure 3. The optimized structure of rGO

Table 1. The comparison of Graphene and rGO

\begin{tabular}{lcc}
\hline Molecular Structure & $\begin{array}{c}\text { HOMO - LUMO } \\
(\mathbf{e V})\end{array}$ & $\begin{array}{c}\text { Total Energy } \\
(\mathbf{H a})\end{array}$ \\
\hline Graphene & -1.094 & -1613.348 \\
rGO & -0.087 & -2051.909 \\
\hline
\end{tabular}

The optimized structure of rGO/PPy is calculated using the same method as the structure before. Figure 4 showed the structure of PPy, which consists of 10 monomers of pyrole. The calculation were done in three different postition of attachement of PPy on $\mathrm{GO}$; at $\mathrm{C}-\mathrm{C}$ bond, $\mathrm{C}-\mathrm{O}$ bond (i.e. replacing the $\mathrm{H}$ atom from hydroxyl) and $\mathrm{N}-\mathrm{C}$ bond. Based on DFT calculations, only rGO/PPy with $\mathrm{C}-\mathrm{C}$ bond linking both structure converge. Table 2 below show the results obtained.

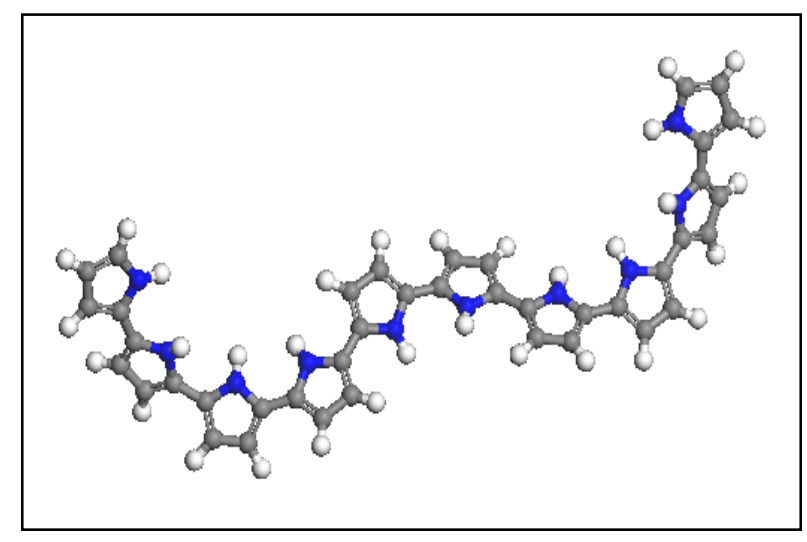

Figure 4. The optimized structure PPy with 10 monomers of pyrole 
Table 2. Comparison between the optimized structure

\begin{tabular}{lcc}
\hline Optimized Molecular Structure & $\begin{array}{c}\text { HOMO }- \text { LUMO } \\
(\mathbf{e V})\end{array}$ & $\begin{array}{c}\text { Total Energy } \\
(\mathbf{H a})\end{array}$ \\
\hline rGO & -0.087 & -2051.909 \\
PPy (10 monomers) & -2.094 & -2091.038 \\
rGO/PPy (C-C) & -0.145 & -4106.005 \\
\hline
\end{tabular}

From Table 2, the lowest energy structure is rGO/PPy composite at C-C bond which is $-4106.005 \mathrm{Ha}$ compared to the other structures. More negative the energy, more stable the structure. This proves that, the rGO/PPy composite possess stability which can be applied as electrode material. The HOMO-LUMO calculation was also done to the structure. The rGO/PPy possesses $-0.145 \mathrm{eV}$ which is slightly greater than rGO. Supposedly, the expected value for $\mathrm{rGO} / \mathrm{PPy}$ is greater than rGO. Due to high eV for PPy, slightly greater energy needed to bind these two materials. Nevertheless, the data obtained is satifactory in giving early conclusion that rGO/PPy is stable to be applied as electrode materials in methanol sensor in DMFC. Further investigation on the binding on both materials is needed.

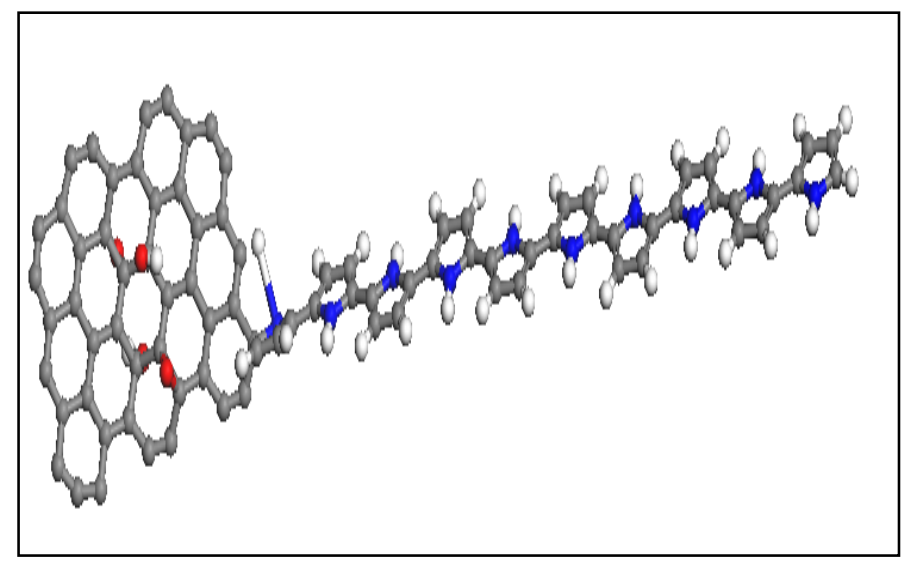

Figure 5. Optimize structure of rGO/PPy composite

\section{Conclusion}

In summary, DFT calculations were successfully applied to determine the lowest energy structure of rGO/PPy. In order to obtain the best result comparison of ideal graphene and rGO are made. It showed that rGO possess more stability than graphene in term of binding energy and also total energy. This is important to prepare rGO as the base in incoporation of polymer matrix, which in this case is PPy. Final optimized rGO/PPy structure is when the C atom of PPy matrix is attached at the $\mathrm{C}$ atom of rGO. The HOMO-LUMO calculated for GO/PPy optimized structure is $-0.145 \mathrm{eV}$ which is higher binding energy than the rGO but lower than graphene. The optimized rGO-PPy is good enough to be applied as electrode material of the methanol sensor but futher calculation should be made.

\section{Acknowledgement}

The authors would like to thank Universiti Kebangsaan Malaysia for the financial support given through GUP2014-071 and Ministry of Higher Education, Malaysia (MOHE) through MyBrain15 (MyMaster) scholarship.

\section{References}

1. Basri, S., Kamarudin, S. K., Daud, W. R. W. and Ahmad, M. M. (2010). Non-linear optimization of passive direct methanol fuel cell (DMFC). International Journal of Hydrogen Energy, 35: 1759 - 1768. 
2. Hashim, N., Kamaruddin S. K. and Daud W. R. W (2010). Design and development of micro direct methanol fuel cell ( $\mu \mathrm{dmfc})$ for portable application. Sains Malaysiana, 39(6): 1015 - 1023.

3. Hassan, M. A., Kamaruddin, S. K., Loh, K. S. and Daud, W. R. W. (2014). Sensors for direct methanol fuel cell. Renewable and Sustainable Energy Reviews, 40: 1060 - 1069.

4. Ahmad, M. M, Kamarudin, S. K. and Daud W. R. W. (2010). Design of an optimal micro direct methanol fuel cell for portable applications. Sains Malaysiana, 39(3): 467 - 472.

5. Bora, C., and Dolui, S. K. (2012). Fabrication of polypyrrole/graphene oxide nanocomposites by liquid /liquid interfacial polymerization and evaluation of their optical, electrical and electrochemical properties. Polymer, 53(4): $923-932$.

6. Potts, J. R., Dreyer, D. R., Bielawski, C. W. and Ruoff, R. S. (2011). Graphene-based polymer nanocomposites. Polymer, 52(1): 5 - 25.

7. Karamdel, J., Damghanian, M., Razaghian, F., Dee, C. F., and B. Yeop Majlis (2010). Dependence of band structure and carrier concentration of metallic $(13,13)$ and semiconducting $(13,0)$ single wall carbon nanotube on temperature. Sains Malaysiana, 39(4): 615 - 620.

8. Dreyer, D. R., Park, S., Bielawski, C. W. and Ruoff, R. S. (2010). The chemistry of graphene oxide. Chemical Society Reviews, 39(1): 228 - 240.

9. Saner, B., Gürsel, S. A. and Yürüm, Y. (2013). Layer-by-layer polypyrrole coated graphite oxide and graphene nanosheets as catalyst support materials for fuel cells. Fullerenes, Nanotubes and Carbon Nanostructures, 21(3): $233-247$.

10. Liu, G., Zhuang, X., Chen, Y., Zhang, B., Zhu, J., Zhu, C.-X., Neoh, K-G. and Kang, E.-T. (2009). Bistable electrical switching and electronic memory effect in a solution-processable graphene oxide-donor polymer complex. Applied Physics Letters, 95(25): 253301.

11. Chandra, V., and Kim, K. S. (2011). Highly selective adsorption of $\mathrm{Hg}^{2+}$ by a polypyrrole-reduced graphene oxide composite. Chemical Communications, (47): 3942 - 3944.

12. Bagri, A., Mattevi, C., Acik, M., Chabal, Y. J., Chhowalla, M. and Shenoy, V. B. (2010). Structural evolution during the reduction of chemically derived graphene oxide. Nature Chemistry, 2(7): $581-587$.

13. Qi, X., Guo, X. and Zheng, C. (2012). Density functional study the interaction of oxygen molecule with defect sites of graphene. Applied Surface Science, 259: $195-200$.

14. Huh, D. S., Basavaraja, C. and Jung, K. W. (2012). Polypyrrole/graphene oxide composites with improved conductivity and solubility. Plastic Research Online, 50: 10 - 11.

15. Liu, Y., Zhang, Y., Ma, G., Wang, Z., Liu, K. and Liu, H. (2013). Ethylene glycol reduced graphene oxide/polypyrrole composite for supercapacitor. Electrochimica Acta, 88: 519 - 525. 